\title{
Mapping higher education for sustainable development in Portugal
}

\author{
Luis Miguel FONSECA \\ Imf@isep.ipp.pt \\ Ana Rita PORTELA \\ University of Minho, Braga, Portugal \\ Beatriz DUARTE \\ University of Minho, Braga, Portugal \\ João QUEIRóS \\ University of Minho, Braga, Portugal \\ Luis PAIVA \\ University of Minho, Braga, Portugal
}

ISEP - P. Porto, School of Engineering and CIDEM R\&D, Porto, Portugal

\begin{abstract}
Education for Sustainable Development (ESD) addresses sustainable development issues, in the economic, environmental, and social dimensions. The positive role of higher education institutions (HEIs), such as Universities and Polytechnic Institutes, in educating decision makers and leaders, and therefore contributing to progress and the public good, has been widely acknowledged. This investigation aims to map the BSc and MSc courses offered by Portuguese HEIs that address Sustainability (or Social Responsibility, or Ethics) in their curricula with the aim of proving their graduates with the right knowledge and competencies to overcome the Sustainable Development challenges. A systematic review utilizing a structured approach was used to analyze Portuguese HEIs BSc and MSc courses and the content analysis of their curricular units. The conclusions show that Sustainability (or Social Responsibility, or Ethics) is covered in most Social Sciences, Engineering, and Management, BSc and MSc courses, offered by the top 8 Portuguese Higher Education Institutions. However, ESD is fragmented by different approaches, issues, methodologies, and implications, lacking a consistent body of knowledge. Some courses focus more on the Social dimension, while others are more directed to the Environment or the Economic one. Sometimes the chosen approach is more normative (do what is right to do; the ethical way) and in other cases is more instrumental (do what is good for the business; the business case). Social Sciences, Engineering and Science, and Management and Economics are the three top clusters that address Sustainability related syllabus in their curricula, with 49 hours teaching hours in average for the curricular units covering Sustainability (with considerable variation). Universities have more curricular units addressing the topic while Polytechnic Institutes show a higher number of hours per curricular unit and most are of compulsory nature (while in Universities more than 50\% of the curricular units are of optional nature). As the collected information was in some cases of generic nature, additional research should be used to confirm and detail these results and evaluate the effectiveness of this education to empower students to act as change agents for Sustainable Development. Benchmarking with other countries (e.g., from the European Union) is also an interesting avenue to pursue this investigation.
\end{abstract}


Keywords: sustainable development, sustainability, social responsibility, circular economy, education, higher education institutions, Portugal.

Please cite the article as follows: Fonseca, L.M., Portela, A.R., Duarte, B., Queirós, J. and Paiva, L. (2018), "Mapping higher education for sustainable development in Portugal", Management \& Marketing. Challenges for the Knowledge Society, Vol., 13, No 3, pp. 1064-1075, DOI: 10.2478/mmcks-2018-0023.

\section{Introduction}

In the last decades, the world has witnessed remarkable improvements in critical economic and social indicators, such as reduction in extreme poverty, improved access to primary education and vaccination, higher literacy rates, diminution in child mortally rates and increase in life expectancy, and the expansion of democracy (WCED, 1987; Carley and Christie, 2000; WCED, 1987; Our World in Data, 2018).

However, humanity must deal with problems of unique dimension and complexity, such as an increasing world population in developing countries, large inequalities in wealth and the threat of climate change (WCED, 1987; Carley and Christie, 2000; WBCSD, 2005; UN, 2015). The concept and approaches of Sustainable Development (SD) aim to integrate people, planet, and profits perspectives on societal development because these issues are global and solving them requires participation by everyone and a multidisciplinary and systemic approach. "Sustainable development is a development that meets the needs of the present without compromising the ability of future generations to meet their own needs" (WECD, 1987) and "it requires simultaneous profitable economic development, social progress and equity, and respect for the environment, while creating value for shareholders, customers, workers, and society at large" (Fonseca, 2015). Stakeholder theory supports the business case for sustainability by stating that the organization that integrates business with social issues create more value for their critical stakeholders and often lead to better operational, economic, and financial performance (Freeman, 1984). Also, at the country level, research shows that is a high correlation (and a possible relationship) between social sustainability, innovation, and competitiveness (Fonseca and Lima, 2015).

In recent years, social responsibility has become a relevant concept that frames the way business acts on sustainability (European Commission, 2002). Although there is no consensus concerning the concept of Sustainability and Corporate Social Responsibility (CSR), the concept of Sustainability will be used as umbrella construct, also for other expressions such as corporate citizenship, triple bottom line, stewardship, stakeholder engagement, business ethics and shared values (Fonseca, 2015).

Scholars recognize that Higher Education Institutions (HEIs) can "catalyze and/or accelerate a societal transition toward sustainability" (Stephens et al., 2010, p.320). However, there is limited knowledge concerning sustainability education in Portugal (Aleixo et al., 2018). Based on the results of an online survey carried out amongst ISEP - P. Porto population (ISEP is one of the five largest engineering schools in Portugal, located at Porto), Fonseca and Domingues (2018) concluded that most respondents agree that it is beneficial both for the environment and the economy the adoption of production systems based on used products, parts reuse, and recycling. 
The authors also found strong support for the selective collection of waste and the adoption of a "zero waste economy" in which all used products or materials are reused or recycled. These conclusions support the effectiveness of the ISEP - P. Porto curricular in addressing SD, however, further investigation is needed to assess if the students and professors really adopt these practices in their personal and professional lives supporting a Circular Economy paradigm to conciliate economic and environmental performance based on improved management of resources (Ellen MacArthur Foundation, 2016).

This investigation is framed within UN Decade of Education for Sustainable Development (DESD) report "Shaping the Future We Want" that calls for the monitoring Education for Sustainable Development (ESD) practice (UNESCO, 2014). It aims to identify the sustainability curricula of Portuguese HEIs and the typology of curricular units that cover them. The system of Higher Education in Portugal is divided into two sub-systems, university, and polytechnic. The overall public network of public HEIs comprises 14 Universities, 20 Polytechnic Institutes and 6 institutions of military and police Higher Education, while the private one comprises 36 Universities and 64 Polytechnic Institutes (Studyinportugal, 2018).

Following a literature review, research of HEIs websites curricula is used to map the existent offer and highlight some conclusions and suggestions for future research. This work has been carried as an assignment with the Curricular Unit "Sustainability and Social Responsibility" of the "Master's in Engineering and Quality Management (MEGQ)" course, offered by the Department of Production and Systems Engineering of the University of Minho, in Braga, Portugal (http://www.dps.uminho.pt/Default.aspx?tabid=19\&pageid=305\&lang=en-US).

\section{Literature review}

Higher education is essential for human development, and the rate of people with this level of education has increased dramatically over the last decades (Schofer and Meyer, 2005). The positive role of higher education institutions (HEIs), such as Universities and Polytechnic Institutes, in educating decision makers and leaders, and therefore contributing to progress and the public good, has been widely acknowledged (Lozano, 2006; Waas et al., 2010). However, there is also evidence that these institutions have been slow to respond to the global sustainability challenges and in some extent may even contribute to aggravate them by focusing on unsustainable models of development (Sterling and Scott, 2008). HEIs need to incorporate SD into their curricula and ensure that their graduates have the rights knowledge and competencies to overcome the SD challenges. In this context, the emphasis of Sustainability on Higher Educations curricula has gained momentum (Wang et al., 2013; Scott, 2012). Dima et al. (2013) proposed a model of social responsibility for the Romanian universities concluding that minimal attention is paid to the role that higher education can and should play in promoting social responsibility. According to Laird et al. (2005), the cultural and management models of universities move higher education away from its larger purpose in contributing to a better and juster society and doesn't prepare the students for their expected roles as future leaders within an increasingly diverse and complex societal environment. 
Following the Bologna Declaration on Higher Education (The EHEA, 1999), the Portuguese HEIs offer 3-year graduation degrees (Basic of Science) and 2-year complementary degrees (Master of Science), although in some circumstances they offer only 5-year integrated courses leading directly to MSc degree. The European Higher Education Area aimed to ensure more comparable, compatible, and coherent systems of higher education within the European Union and for a sustainability-based curriculum to be successful, the way courses are offered, and content is delivered, require a robust multidisciplinary approach (Blackburn, 2016). Given the complexity transversal nature of sustainability issues, students should be able to make connections between concepts and across disciplines (Wright, 2004).

Education for Sustainable Development (ESD) addresses sustainable development issues, in all the three SD dimensions (Corney and Reid, 2007) and the United Nations Decade on Sustainable Development in Education (2005) advanced for the inclusion of the principles of sustainable development in national education curricula, as a relevant measure to achieve sustainability. The UN's publication "Transforming our World: the 2030 Agenda for Sustainable Development" contains 17 Sustainable Development Goals that should be addressed in an integrative and indivisible way balancing the economic, social and environmental dimensions of sustainable development (UN, 2015). In addition to this, many scholars in the field of ESD consider a comprehensive approach to the SD concept important (Sandell et al., 2005). Scholars have been arguing that HEIs should focus more on the development of skills like critical thinking and moral reasoning (Podolny, 2009) and actively promote sustainability (Amaral et al., 2015; Godemann et al., 2014). Overall, there is an agreement to include the triple bottom line as the central basis for sustainability education (Figueiro and Raufflet, 2015). However, as a field of knowledge, sustainability education is considerably fragmented with different theoretical approaches, issues, methodologies, and implications, lacking a consistent body of knowledge (Figueiro and Raufflet, 2015). Researchers have identified several barriers to incorporation Sustainability syllabus in HEIs curricula since it requires different types of knowledge (Adomßent et al., 2013) and driving paradigms (Halbe et al., 2015) to overcome resistance to change, disciplinary boundaries and the separation of subjects. Additionally, few studies have addressed the existing higher education for sustainable development (HESD) offer in Portugal (Aleixo et al., 2018) and this investigation aims to contribute to fulfilling this research gap.

\section{Methodology}

This paper research is based on a structured approach to analyze the Portuguese HEIs BSc and MSc courses and the content analysis of the curricular units. This systematic review was conducted in four steps, namely, (1) HEIS identification, (2) BSc and MSc courses offer, (3) curricular unit content analysis, (4) results analysis and discussion. Although the curricula main purpose is to support teaching and learning and cannot be considering accurate records of the teaching that have occurred, the decision to use documented information from the HEIs websites was taken, since it is publicly available and no previous permissions for its use are required.

For the first step of the research methodology, the top 4 Portuguese Universities and 4 Polytechnic Institutes in Portugal were identified and selected from 
the Ranking Web of Universities January 2017 (UP, 2018). In the second step, the BSc and MSc courses offered by these 8 HEIs (total of 52 courses) were analyzed by accessing their websites. For the third one, all the curricular units (464 in total) of the 52 BSc and MSc, from the 8 top Portuguese HEIs, were scrutinized, to identify those that addressed Sustainability (or Social Responsibility, or Ethics), the nature of the curricular unit (compulsory or optional) and the applicable number of teaching hours. Since the available information was in some cases of generic and subjective nature, professors of the Master's in Engineering and Quality Management offered by Minho University were interviewed and the researchers' knowledge of the investigation context was also used, to reinforce the credibility of this analysis. Finally, the statistical distribution of the percentage of curricular units covering Sustainability and Sustainable Development (as the approach to achieve it) the number of hours and the nature of these curricular units were calculated. Since there are two HE subsystems in Portugal, Universities, and Polytechnics, the following research question was tested: there is a difference between the number of hours addressing Sustainability in the curricula of Universities versus Polytechnics. The statistical analysis and the statistical hypothesis testing were carried out supported in the outputs collected from the IBM SPSS v. 23.

\section{Results and Discussion}

The 4 top Portuguese Universities and Polytechnic Institutes, according to the Web of Universities ranking (January 2017) are presented in Table 1:

Table 1. Portuguese 8 top HEIs according to Web of Universities ranking

\begin{tabular}{|l|c|c|c|}
\hline HEI & $\begin{array}{l}\text { World } \\
\text { Rank }\end{array}$ & $\begin{array}{l}\text { Europa } \\
\text { Rank }\end{array}$ & $\begin{array}{l}\text { Portugal } \\
\text { Rank }\end{array}$ \\
\hline $\begin{array}{l}\text { UPorto: Porto University (Universidade do Porto: } \\
\text { https://sigarra.up.pt/up/en/WEB_BASE.GERA_PAGINA?p_pagina= } \\
\text { home) }\end{array}$ & 181 & 55 & 1 \\
\hline $\begin{array}{l}\text { ULisbon: Lisbon University (Universidade de Lisboa- } \\
\text { https://www.ulisboa.pt/en) }\end{array}$ & 267 & 107 & 2 \\
\hline $\begin{array}{l}\text { UCoimbra: Coimbra University (Universidade de Coimbra: } \\
\text { http://www.uc.pt/en) }\end{array}$ & 306 & 170 & 3 \\
\hline $\begin{array}{l}\text { UMinho: Minho University (Universidade do Minho: } \\
\text { https://www.uminho.pt/EN/Pages/default.aspx) }\end{array}$ & 389 & 170 & 4 \\
\hline $\begin{array}{l}\text { IPPorto: Porto Polytechnic Institute (Instituto Politécnico do } \\
\text { Porto: https://www.ipp.pt/?set_language=en) }\end{array}$ & 1072 & 451 & 5 \\
\hline $\begin{array}{l}\text { IPBragança: Bragança Polytechnic Institute (Instituto Politécnico } \\
\text { de Bragança: http://portal3.ipb.pt/index.php/en/ipben/home) }\end{array}$ & 1072 & 636 & 6 \\
\hline $\begin{array}{l}\text { IPLisboa: Lisbon Polytechnic Institute (Instituto Politécnico de } \\
\text { Lisboa: https://www.ipl.pt/en) }\end{array}$ & 1831 & 673 & 7 \\
\hline $\begin{array}{l}\text { IPLeiria: Leiria Polytechnic Institute (Instituto Politécnico de } \\
\text { Leiria: https://www.ipleiria.pt/home/) }\end{array}$ & 1870 & 686 & 8 \\
\hline
\end{tabular}

Source: UP, 2018.

From these 8 HEIS websites, a total of 52 courses and 464 curricular units were analyzed and 58 curricular units were identified as addressing Sustainability syllabus (12.5\% of total), with $14 \%$ for the 4 Universities and $10 \%$ for the 4 Polytechnic Institutes. There are three main course clusters that address 
Sustainability related syllabus in their curricula: Social Sciences $(40 \%$ of total), Engineering and Science (35\%) and Management and Economics (23\%), as presented in Figure 1.

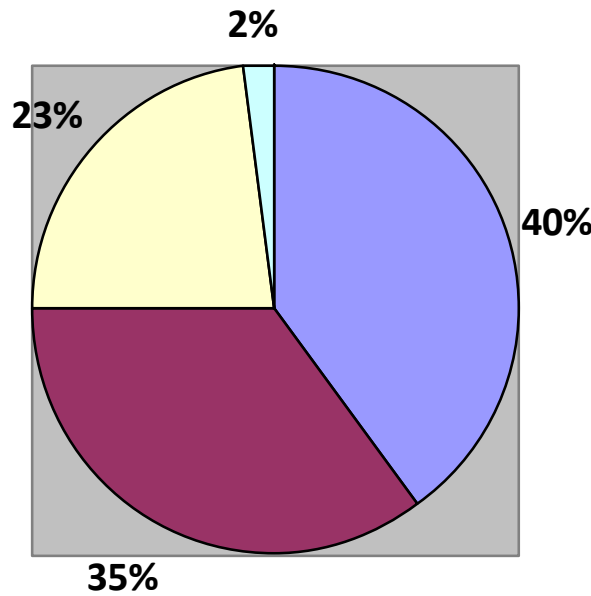

$\square$ Social Sciences

$\square$ Engineering and Sciences

$\square$ Management and

Economics

$\square$ Other

\section{Figure 1. Distribution of Courses Areas addressing Sustainability by the 8 Top Portuguese HEIs}

Source: Authors' own elaboration.

The descriptive statistics for the 8 HEIs, in terms of curricular units (CU), are presented in Table 2:

Table 2. Sustainability Curricular units' descriptive statistics

\begin{tabular}{|l|c|c|c|c|}
\hline 8 HEIs & Minimum & Maximum & Mean & $\begin{array}{l}\text { Standard } \\
\text { Deviation }\end{array}$ \\
\hline $\begin{array}{l}\text { Number of CU } \\
\text { addressing } \\
\text { Sustainability }\end{array}$ & 3 & 18 & 7.25 & 5.01 \\
\hline $\begin{array}{l}\text { Number of } \\
\text { teaching hours for } \\
\text { those CU }\end{array}$ & 36 & 107.50 & 48.69 & 23.98 \\
\hline
\end{tabular}

Source: Authors' own elaboration.

Figure 2 presents the distribution of the CU addressing Sustainability by the top 8 Portuguese HEIs: 


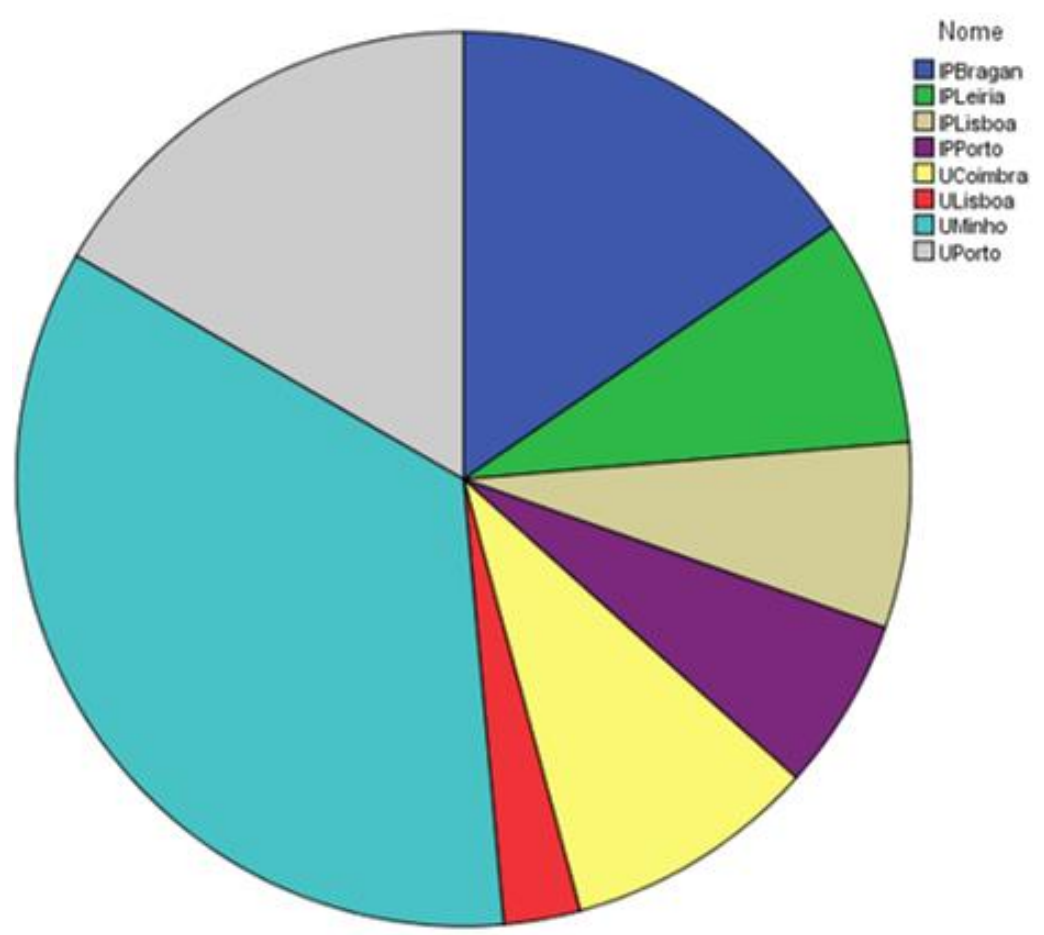

Figure 2. Distribution of CU addressing Sustainability by the 8 Top Portuguese HEIs

Source: Authors' own elaboration.

To assess if there is statistically significant difference between the number of hours addressing Sustainability in the curricula of the 4 Top Universities versus the 4 Top Polytechnics, statistical tests were carried on as summarized in Table 3 and Figure 3 (SPSS output):

Table 3. Descriptive statistics of Sustainability teaching hours by BSc and MSc courses

\begin{tabular}{|l|l|l|l|l|}
\hline Type of HEI & $\mathrm{N}$ & $\begin{array}{l}\text { Mean Hours } \\
\text { Sustainability }\end{array}$ & $\begin{array}{l}\text { Standard } \\
\text { Deviation }\end{array}$ & $\begin{array}{l}\text { Mean Standard } \\
\text { Error }\end{array}$ \\
\hline University & 4 & 40.500 & 3.000 & 1.5000 \\
\hline Polytechnic & 4 & 58.875 & 33.957 & 16.978 \\
\hline
\end{tabular}

Source: Authors' own elaboration.

Figure 3. Statistical Tests (SPSS Output)

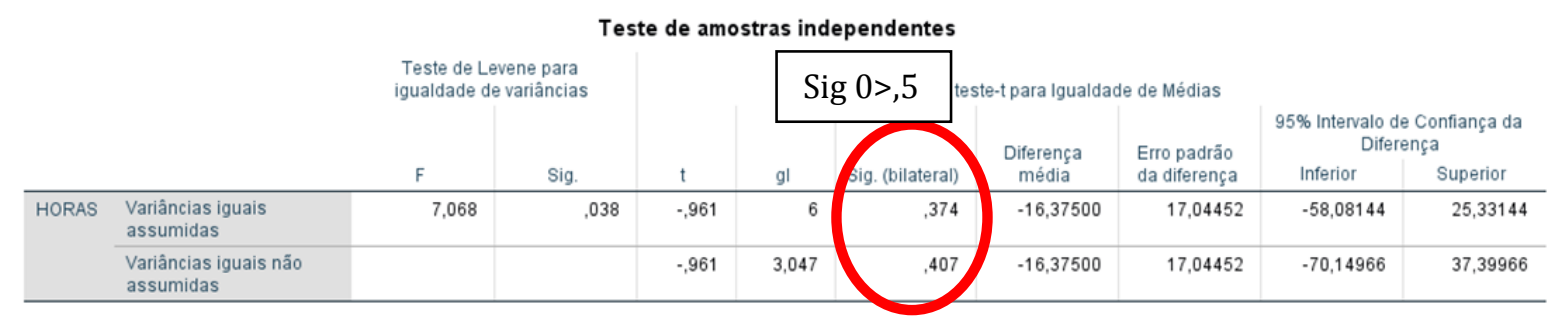

Source: Authors' own elaboration. 
Due to the sig value of the test, although the sample mean of the Sustainability related curricular units is higher for Polytechnics than for Universities, we cannot assume it with 95\% confidence.

The main conclusions of the analysis of the research results can be summarized as follows:

- In the top 4 Universities and the 4 Polytechnic Institutes, an average of 7 BSc and MSc courses, and 12.5\% curricular units cover Sustainability contents, with $14 \%$ for the 4 Universities and $10 \%$ for the 4 Polytechnic Institutes;

- 3 clusters address Sustainability related syllabus in their curricula: Social Sciences (40\% of total), Engineering and Science (35\%) and Management and Economics (23\%) BSc and MSc courses;

- The average teaching hours of the curricular units covering Sustainability is 49 hours. The Universities have, on average, more curricular units covering Sustainability, however, in the Polytechnic Institutes the average number of hours per curricular unit is higher and most are of compulsory nature (while in Universities more than $50 \%$ of the curricular units are of optional nature).

\section{Conclusion}

This investigation identified that Sustainability (or Social Responsibility, or Ethics) is covered in most Social Sciences, Engineering and Management, BSc, and MSc courses, offered by the top 8 Portuguese Higher Institutions. However, Sustainability education is fragmented by different approaches, issues, and methodologies, and implications, lacking a consistent body of knowledge. Some courses focus more on the Social dimension, while others are more directed to the Environment or the Economic one. Sometimes the applied approach is more normative (do what is right; the ethical way) and in other cases is more instrumental (do what is good for the business, the business case). In some HEIs, the curricular units are more of optional nature, while in others they are compulsory. The Portuguese secondary education system (lower degree before High Education) already introduces the concepts of Sustainable Development to students and the main challenges of climate change, population growth and eco-systems preservation, that need to be addressed to ensure a sustainable future. At the HEIs level, the aim is to provide students with the knowledge and competencies needed to empower them to act as active agents to materialize the Sustainable Development Goals and contributing to change the societal ways of life and the way business is done. There are 3 clusters that address Sustainability related syllabus in their curricula, namely Social Sciences, Engineering and Science and Management and Economics. The average teaching hours of the curricular units covering Sustainability is 49 hours (with considerable variation), with the Social Science cluster more focused on the social dimension, the Engineering one addressing primarily environmental and technical issues and the last cluster of Management and Economics emphasizing the economic perspective Universities have, on average, more curricular units covering Sustainability, while the Polytechnic Institutes show a higher number of hours per curricular unit and most are of compulsory nature (while in Universities more than $50 \%$ of the curricular units are of optional nature). It is recognized that the balance between diversity and 
standardization is not easy to attain since it requires different types of knowledge and driving paradigms to overcome resistance to change, disciplinary boundaries and the separation of subjects. A recommended approach to overcome these issued would be to use more transdisciplinary approaches and foster the partnerships between the several HEIs and between Business and HEIs, through sponsoring, collaborative research, curriculum development and delivering and academics/students mobility (Ghinea et al. 2017).

The information available on the accessed websites was in some cases of generic nature and didn't allow an in-depthanalysis of the curricular units' syllabus and contents. Education for Sustainable Development takes into consideration multiple stakeholders, and there are different philosophical, scientific and methodological perspectives involved, which results in many different avenues to ensure that students have the necessary skills. Although the 8 Top Portuguese HEIs considered in this research expect that their students will have the required knowledge and competencies for Sustainable Development, further investigation is needed to evaluate the effectiveness of these different approaches and methodologies to empower students to act as change agents for Sustainability in their future professional and societal environments. Fonseca et al. (2018), based on an empirical investigation with 99 Portuguese firms, highlighted that there is agreement within the surveyed organizations that "Academia should focus on the dissemination and creation of knowledge in Sustainable Development and the Circular Economy", so an interesting topic for future investigations is to assess the real effectiveness of HEIs education in that regard. Moreover, some other relevant Portuguese HEIs were not analyzed since this investigation was restricted to the 8 Top ones. It is suggested to use additional investigation methodologies to reinforce the results validity and compare these results with other European Union countries to assess the different approaches within the Bologna Declaration universe.

\section{References}

Adomßent, M., Fischer, D., Godemann, J., Herzig, C., Otte, I., Rieckmann, M., Timm, J. (2014), "Emerging areas in research on higher education for sustainable development management education, sustainable consumption and perspectives from Central and Eastern Europe", Journal of Cleaner Production, Vol. 62, pp. 1-7, doi: 10.1016/j.jclepro.2013.09.045.

Aleixo, A.M., Leal, S., Azeiteiro, U.M. (2018), “Conceptualization of sustainable higher education institutions, roles, barriers, and challenges for sustainability: An exploratory study in Portugal", Journal of Cleaner Production, Vol. 172, pp. 1664-1673, doi: 10.1016/j.jclepro.2016.11.010.

Amaral, L.P., Martins, N., Gouveia, J.B. (2015), “Quest for a sustainable university: a review", International Journal of Sustainability in Higher Education, Vol. 16, No. 2, pp. 155-172, doi: 10.1108/IJSHE-02-2013-0017.

Blackburn, W.R. (2016), "The practice of sustainability at colleges and universities", Environmental Law Reporter News \& Analysis, Vol. 46, No. 5, pp. 10394-10385.

Cortese, A.D. (2003), "The critical role of higher education in creating a sustainable future", Planning for Higher Education, Vol. 31, No. 3, pp. 15-22. 
Carley, M., Christie, I. (2000), Managing Sustainable Development, Second ed., Earthscan Publications Ltd.: London.

Corney, G., Reid, A., (2007), “Student teachers' learning about subject matter and pedagogy in education for sustainable development", Environmental Education Research, Vol. 13, No. 1, pp. 33-54, doi: 10.1080/13504620601122632.

Dima, A.M., Vasilache, S., Ghinea, V., Agoston, S. (2013), "A model of Academic Social Responsibility", Transylvanian Review of Administrative Sciences, Vol. 38, pp. 23-43.

Dima, A.M., Hadad, S., Luchian, J. (2017), "Review on the dimensions of businessuniversity alliances", in: Proceedings of the 11th International Conference on Business Excellence, pp. 64-73, doi: 10.1515/picbe-2017-0007.

Ellen Macarthur Foundation (2014). Towards the Circular Economy, Vol. 3: Accelerating the scale-up across global supply chains. Ellen Macarthur Foundation: Cowes.

European Commission, (2002), "Communication from the Commission Concerning Corporate Social Responsibility: A Business Contribution to Sustainable Development", available

http://trade.ec.europa.eu/doclib/docs/2006/february/tradoc_127374.pdf (accessed March 21, 2015).

Fonseca, L.M. (2015), "Strategic Drivers for Implementing Sustainability Programs in Portuguese Organizations- Let's Listen to Aristotle: From Triple to Quadruple Bottom Line", Sustainability: The Journal of Record (USA), Vol. 8, No. 3, pp. 136142, doi: 10.1089/SUS.2015.29004.

Fonseca, L., Lima, V. (2015), “Countries three Wise Men: Sustainability, Innovation, and Competitiveness", Journal of Industrial Engineering and Management, Vol. 8, No. 4, pp. 1288-1302, doi: 10.3926/jiem.1525.

Fonseca, L.M. and Domingues, J.P. (2018), Adoption of Circular Economy concepts and practices by Portuguese Citizens and Companies, in Proceedings of the 12th International Conference on Business Excellence 2018, 12 (1), pp. 374-385. DOI: https://doi.org/10.2478/picbe-2018-0033.

Fonseca, L.M., Domingues, J.P., Pereira, M.T., Martins, F.F. and Zimon, D. (2018), Assessment of Circular Economy within Portuguese Organizations. Sustainability, 10, 2521; doi:10.3390/su10072521.

Figueiró P.S., Raufflet E. (2015), "Sustainability in higher education_ a systematic review", Journal of Cleaner Production, Vol. 106, pp. 22-33, doi: 10.1016/j.jclepro.2015.04.118.

Freeman RE. Strategic Management (1984), “A Stakeholder Approach”, Pitman: Boston. Ghinea, V.M., Dima, A.M. and Hadad, S. (2017), "Excellence Model for Sustainable Convergence in the EU Higher Education", Amfiteatru Economic, Vol. 19 (Special No. 11), pp. 1107-1122.

Godemann, J., Bebbington, J., Herzig, C., Moon, J. (2014), "Higher education and sustainable development: exploring possibilities for organisational change", Auditing Accounting Journal, Vol. 27, pp. 218-233, doi: 10.1108/AAAJ-12-20131553. 
Halbe, J., Adamowski, J., Pahl-Wostl, C. (2015), "The role of paradigms in engineering practice and education for sustainable development", Journal of Cleaner Production, Vol. 106, pp. 272-282, doi: 10.1016/j.jclepro.2015.01.093.

Laird, T.F.N., Engberg, M.E. and Hurtado, S. (2005), "Modeling Accentuation Effects: Enrolling in a Diversity Course and the Importance of Social Action Engagement", The Journal of Higher Education, Vol. 76, No. 4, pp. 448-476 doi: 10.1080/00221546.2005.11772292.

Lozano, R. (2006), "Incorporation and institutionalization of SD into universities: breaking through barriers to change", Journal of Cleaner Production, Vol. 14, pp. 787-796, doi: 10.1016/j.jclepro.2005.12.010.

Our World in Data (2018), available at https://ourworldindata.org/ (accessed February 27, 2018).

Podolny, J.M. (2009), "The Buck Stops (and Starts) at Business School", Harvard Business Review, Vol. 87, No. 6, pp. 62-67.

Sandell, K., Ohman, J., Ostman, L. (2005), Education for Sustainable Development: Nature, School and Democracy. Studentlitteratur: Lund.

Schofer, E., Meyer, J.W. (2005), "The worldwide expansion of higher education in the twentieth century", American Sociological Review, Vol. 70, No. 6, pp. 898-920, doi: $10.1177 / 000312240507000602$.

Scott, W. (2012), "Sustainability education e perspectives and practice across higher education", Environmental Education Research, Vol. 18, No. 5, pp. 722-726, doi: 10.1080/13504622.2012.662394.

Stephens, J.C., Graham, A.C. (2010), "Toward an empirical research agenda for sustainability in higher education: exploring the transition management framework", Journal of Cleaner Production, Vol. 18, No. 7, pp. 611-618, doi:10.1016/j.jclepro.2009.07.009.

Sterling, S., Scott, W. (2008), "Editorial", Environmental Education Research, Vol. 14, No. 4, pp. 383-385, doi: 10.1080/13504620802343862.

Studyinportugal

Available

at http://www.studyinportugal.edu.pt/index.php/study/portuguese-highereducation (accessed April 10, 2018).

The European Higher Education Area (1991), Available at http://www.ehea.info/ (accessed February 28, 2018).

United Nations Development Programme (2008), Fighting Climate Change: Human Solidarity in a Divided World. Human Development Report, 2007/2008, United Nations Development Programme, New York.

UN (2015), Transforming Our World: the 2030 Agenda for Sustainable Development, September 25. United Nations General Assembly, New York, Available at http://www.un.org/ga/search/view_doc.asp?symbol1/4A/RES/70/1\&Lang1/4E.

The United Nations Educational, Scientific and Cultural Organization (2005). The DESD at a Glance. UNESCO - Education for Sustainable Development. UN Decade of Education for Sustainable Development 2005-2014. Division for the Promotion of Quality Education, 2005. Available online: https://en.unesco.org/themes/education-sustainable-development (accessed on 30 November 2017). 
UNESCO (2014), Shaping the Future We Want. UN Decade of Education for Sustainable Development (2005-2014). Final report. Paris: UNESCO.

UP (2018). Ranking Web of Universities, available at https://sigarra.up.pt/up/pt/conteudos_service.conteudos_cont?pct_id=27246 \&pv_cod=41iLDJJjWrFH [accessed 27/02/2018).

Waas, T., Verbruggen, A.,Wright, T. (2010), "University research for sustainable development: definition and characteristics explored", Journal of Cleaner Production, Vol. 18, pp. 629-636, doi: 10.1016/j.jclepro.2009.09.017

Wang, Y., Wang, R., Shi, H., Huisingh, D., Hansson, L., Hong, J. (2013), Special issue: green universities and environmental higher education for sustainable development in China and other emerging countries, Journal of Cleaner Production, Vol. 61, pp. 1-138.

WCED (1987), Our Common Future: a Report from the United Nations World Commission on Environment and Development. Oxford: Oxford University Press, available at: http://www.un-documents.net/our-common-future.pdf.

WBCSD-World Business Council for Sustainable Development (2007), Doing Business with the World. World Business Council for Sustainable Development, Development Focus Area, New York, available at http://www.wbcsd.org/Pages/EDocument/EDocumentDetails.aspx?ID=46\&N oSearchContextKey=true (last accessed 3/23/2015).

Wright, Tara. (2004), The Evolution of Sustainability Declarations in Higher Education". In P. B. Corcoran \& A.E.J. Wals (Eds.), Higher Education and the Challenge of Sustainability: Problematics, Promise and Practice, (pp. 7-19), Springer: Dordrecht. 